\title{
Identification of Single Nucleotide Polymorphism in Y- chromosome Specific DDX3Y Gene in Murrah Buffalo Bulls
}

\author{
P. Ramajayan, S.N. Sivaselvam, S.M.K. Karthickeyan, A. Gopinathan, S. Poobitha ${ }^{1}$
}

10.18805/IJAR.B-4692

\begin{abstract}
Background: Molecular markers based approaches are essential to select fertile bulls for frozen semen production at an early age. The present investigation was undertaken to perform the molecular characterization and identify single nucleotide polymorphisms (SNP) in Y-chromosome specific DDX3Y gene in Murrah buffalo bulls.

Methods: The genomic DNA isolated from the blood samples of 70 Murrah buffalo bulls, covering bulls with normal seminal traits and poor production performance (poor semen quality, freezability, libido), were subjected to PCR amplification. The sequences of DDX3Y gene were analyzed for single nucleotide polymorphism using the seqman module of DNASTAR LASERGENE software. The single nucleotide variations in the sequences with reference to the Bos taurus sequence were determined using Clustal W. The phylogenetic tree and genetic distance were constructed using the MegAlign module.

Result: The analysis of sequences revealed that the exons and their adjacent intronic regions of the DDX3Y gene are monomorphic in nature without any variations indicating that the sequences are highly conserved in the studied population of Murrah buffalo bulls. However, a considerable number of single nucleotide variations were observed in the sequences of Murrah buffalo compared with Bos taurus sequences. Furthermore, the phylogenetic tree analysis revealed less divergence and close genetic association between the sequences of Murrah buffalo and other species in the bovinae family than the caprinea species. Further studies on $D D X 3 Y$ gene in a more extensive and diverse population of Murrah buffalo bulls distributed in different regions could aid to discover substantial SNPs.
\end{abstract}

Key words: $D D X 3 Y$ gene, Monomorphic, Murrah buffalo bull, Y-chromosome.

\section{INTRODUCTION}

The modern breeding program using frozen semen from genetically superior bulls through artificial insemination is extensively used to improve economically important traits. Semen production and fertility index of bulls are complex traits which are influenced by both genetic and environmental factors. Identifying bulls with high genetic merit is very important for quality frozen semen production, as bulls selected for semen production are often culled due to poor reproductive performance. The development of molecular markers based approaches is essential for the selection of breeding bulls, which accurately predicts the reproductive efficiency of the bulls at an early age.

The semen production is primarily governed by the clusters of genes in the male-specific region of $Y$ chromosome, which plays a significant role in reproduction, sexual development, sex differentiation, spermatogenesis and spermatogenic cells structural and functional integrity (Mukherjee et al., 2013). The Y-specific genes regulating the process of semen production could be considered as potential candidate genes to determine the bull's fertility. Therefore, identifying single nucleotide polymorphisms in these candidate genes would help to develop potential genetic markers for selecting quality bulls through Marker Assisted Selection (MAS). However, only few Y-chromosome specific genes (SRY, TSPY, RBMY and ZNF280BY) have been investigated for the polymorphisms associated studies in buffaloes (Mukhopadhyay et al., 2011; Kaur et al., 2014; Revanasiddu et al., 2019), but still, Y-specific genes like
Department of Animal Genetics and Breeding, Madras Veterinary College, Tamil Nadu Veterinary and Animal Sciences University, Chennai-600 051, Tamil Nadu, India.

${ }^{1}$ Department of Veterinary Pathology, Rajiv Gandhi Institute of Veterinary Education and Research, Puducherry-605 009, Tamil Nadu, India.

Corresponding Author: P. Ramajayan, Department of Animal Genetics and Breeding, Madras Veterinary College, Tamil Nadu Veterinary and Animal Sciences University, Chennai-600 051, Tamil Nadu, India. Email: dr.ramvet1990@gmail.com

How to cite this article: Ramajayan, P., Sivaselvam, S.N., Karthickeyan, S.M.K., Gopinathan, A. and Poobitha, S. (2021). Identification of Single Nucleotide Polymorphism in Y-chromosome Specific $D D X 3 Y$ Gene in Murrah Buffalo Bulls. Indian Journal of Animal Research. DOI: 10.18805/IJAR.B-4692.

Submitted: 23-06-2021 Accepted: 16-11-2021 Online: 01-01-2021

DDX3Y, USP9Y, HSFY, PRAMEY, etc. are yet to be explored in buffaloes.

DEAD-box polypeptide 3 Y-linked (DDX3Y) gene (also known as $D B Y$ ) belongs to the DEAD (Asp-Glu-Ala-Asp) box protein family, which is involved in ATP-dependent RNA unwinding and other cellular activities like slicing, ribosome biogenesis and RNA degradation (Gueler et al., 2012 and Ramathal et al., 2015). DDX3Y gene transcript functions are testis-specific, the proteins are expressed predominantly in male germ cells, indicating its role in the spermatogenic process and spermatocyte development (Liu et al., 2009). The mutations in this gene were associated with the reduced 
number of sperm cells, structural deformities, male subfertility and infertility in humans (Ramathal et al., 2015 and Liu et al., 2009). Hence, the present study was undertaken to identify single nucleotide polymorphism in the Y- chromosome specific DDX3Y gene in Murrah buffalo bulls.

\section{MATERIALS AND METHODS Experimental animals}

Blood samples were collected from 70 Murrah buffalo bulls maintained in the frozen semen production station, Exotic Cattle Breeding Farm, Thanjavur, Tamil Nadu, India. Bulls with normal seminal traits (42) and poor semen production performance i.e., $<60 \%$ initial motility (17), $<50 \%$ post-thaw motility (7) and poor libido (4) were selected for the study. The experiment was performed in 2016 at the Department of Animal Genetics and Breeding, Madras Veterinary College, Chennai.

\section{DNA extraction}

About $10 \mathrm{ml}$ of blood was collected aseptically from the jugular vein and transferred to sterile Becton-Dickinson vacutainer precoated with $0.5 \%$ of $0.12 \mathrm{ml}$ EDTA. The genomic DNA was extracted from the blood samples by organic method (Sambrook et al., 1989). The quality of DNA was checked in $0.8 \%$ agarose using horizontal gel electrophoresis with $0.5 \mathrm{X}$ TAE as running buffer. The concentration and purity were estimated with Nanodrop Biospectrophotometer using millipore water as blank reference.
Based on concentration, the DNA samples were diluted with sterile nuclease-free water to working solution of 20 to 50 $\mathrm{ng} / \mu \mathrm{l}$ and stored at $-20^{\circ} \mathrm{C}$.

\section{Primer designing}

The primers for the exons of $D D X 3 Y$ gene were designed with "Primer3" online software (http://frodo.wi.mit.edu/ primer3) using Bos taurus DDX3Y gene sequence (Gene ID with accession number: 783057 - NM_0011725951.1) as reference. The sequence of exons was selected along with the intronic regions for the proper amplification of the entire exons. The Oligo Analyzer 1.0.3 software was used to analyse the primers for self-annealing, GC content and primer loops to obtain the best pair of primers. The primers working concentration of 10 picomoles were prepared from the stock concentration of $100 \mathrm{pmol} / \mu \mathrm{l}$ using nuclease-free water. The primer sequences, their corresponding product sizes and annealing temperatures are presented in Table 1.

\section{PCR amplification}

The polymerase chain reaction (PCR) was performed in $15 \mu$ reaction volume with $25-50 \mathrm{ng}$ of genomic DNA, primers and PCR master mix using thermal cyclers. The annealing temperature of each primer was standardized by gradient PCR, based on the quality yield of specific PCR products. About $3 \mu$ of PCR products along with $50 \mathrm{bp}$ DNA ladder was checked in $2 \%$ agarose gel holding $0.5 \mu \mathrm{g} / \mathrm{ml}$ ethidium bromide. The gels were run at a voltage of $100 \mathrm{~V}$ for 45 minutes and the product size was visualized under UV trans-

Table 1: Primer sequences of $D D X 3 Y$ gene for $P C R$ amplification.

\begin{tabular}{|c|c|c|c|c|}
\hline Primer name & Primer sequence $\left(5^{\prime} \rightarrow 3^{\prime}\right)$ & Regions & $\mathrm{T}_{\mathrm{a}}\left({ }^{\circ} \mathrm{C}\right)$ & Product size $(b p)$ \\
\hline \multirow[t]{2}{*}{ DDX3Y I } & F: CGTTTAAATACACCCCCAAG & Exon 1 & 52.9 & 502 \\
\hline & R: AGGAACCAGCAAAAGGAAGA & & & \\
\hline \multirow[t]{2}{*}{ DDX3Y II } & F: GTGTGTATGACTGGAATTTAGGACT & Exon 2 & 60 & 319 \\
\hline & R: CACACTTGAAAAGAACCAACTAGTC & & & \\
\hline \multirow[t]{2}{*}{ DDX3Y III } & F: CCAGCTATGTCTGGGAAATGTG & Exons 3-4 & 61.5 & 895 \\
\hline & R: AAGCACAGACGGGAGGGAAA & & & \\
\hline \multirow[t]{2}{*}{ DDX3Y IV } & F: CAGATAACCACAGCTAAATTGGAAG & Exons $5-6$ & 61 & 654 \\
\hline & R: ACATTAGTCACCAGTCTCTCCT & & & \\
\hline \multirow[t]{2}{*}{ DDX3Y V } & F: GACAGACATTGACAGACATT & Exon 7 & 54 & 527 \\
\hline & R: АCTTTCCCTTCACCGACTCC & & & \\
\hline \multirow[t]{2}{*}{ DDX3Y VI } & F: CACAAATCATCCAGCATTCTTCAC & Exons 8-9 & 58.2 & 709 \\
\hline & R: GACCAATATCAGCACCACCG & & & \\
\hline \multirow[t]{2}{*}{ DDX3Y VII } & F: TCTCCTTGGTTTTAGCCCCA & Exons 10 & 61.4 & 402 \\
\hline & R: CCACTCCAGTACTCTTGCCT & & & \\
\hline \multirow[t]{2}{*}{ DDX3Y VIII } & F: TGGCTATGTGATCTGTATGTGGT & Exons $11-12$ & 55 & 598 \\
\hline & R: ACAGGGTACAGGCTAAAGGT & & & \\
\hline \multirow[t]{2}{*}{ DDX3Y IX } & F: TACCTTTAGCCTGTACCCTG & Exons $13-14$ & 61 & 840 \\
\hline & R: TGGCACTTCTTGTTTGGCTT & & & \\
\hline \multirow[t]{2}{*}{ DDX3Y X } & F: TGGTTGCTTGATGGTTTGACA & Exons $15-16$ & 61.5 & 978 \\
\hline & R: GAAGCCTCCATAGCCACCTA & & & \\
\hline \multirow[t]{2}{*}{ DDX3Y XI } & F: CAGCAGCAGAGGATTTGGTG & Exon 17 & 53.5 & 441 \\
\hline & R: GGAGAATCACTATGGGTAATGCA & & & \\
\hline
\end{tabular}

F-Forward; R-Reverse; $T_{a}$ - Annealing temperature. 
illuminator and documented by gel documentation system. The composition of the PCR reaction mixture and thermocycle conditions are furnished in Tables 2 and 3.

\section{Sequencing and analysis}

The PCR amplicons were sequenced in both forward and reverse directions by M/s. SciGenom Labs Pvt. Ltd., Cochin. The "Seqman module" of DNASTAR LASERGENE software for multiple sequence analysis was used to identify the single nucleotide polymorphism within the sequences of Murrah buffalo bulls taking Bos taurus DDX3Y gene sequence as reference. Clustal $W$ sequence alignment (MegAlign

Table 2: Composition of PCR reaction mixture.

\begin{tabular}{lc}
\hline Components & Volume $(\mu \mathrm{l})$ \\
\hline Master mix (Ampliqon) & 7.5 \\
Primer - Forward and reverse (10 pmoles) & $0.5-1.0$ \\
Template DNA & $1.5-2.0$ \\
Millipore water & $5.5-4.5$ \\
\hline
\end{tabular}

Table 3: PCR reaction condition.

\begin{tabular}{llcc}
\hline Step & Process & Temperature & Duration \\
\hline 1 & Initial denaturation & $95^{\circ} \mathrm{C}$ & 5 minutes \\
2 & Cyclic denaturation & $95^{\circ} \mathrm{C}$ & 45 seconds \\
3 & Primer annealing & $\begin{array}{c}\text { Varied with } \\
\text { the primer }\end{array}$ & $35-45$ seconds \\
& & $72^{\circ} \mathrm{C}$ & $45-60$ seconds \\
4 & Primer extension & 35 cycles & \\
5 & Back to steps 2 to 4 & $72^{\circ} \mathrm{C}$ & $7-10$ minutes \\
6 & Final extension & $4^{\circ} \mathrm{C}$ & For ever \\
7 & Hold & & \\
\hline
\end{tabular}

module) was used to determine the single nucleotide variations between the sequences of Murrah buffalo and Bos taurus. The phylogenetic tree and genetic distance were constructed for pairwise sequence alignment under Neighbour-Joining (NJ) with 1000 bootstrap using the MegAlign module.

\section{RESULTS AND DISCUSSION}

The $D D X 3 Y$ gene consists of 17 exons with a sequence length of $130 \mathrm{bp}, 134 \mathrm{bp}, 154 \mathrm{bp}, 118 \mathrm{bp}, 182 \mathrm{bp}, 145 \mathrm{bp}$, 145 bp, 161 bp, 99 bp, 86 bp, 136 bp, 101 bp, 159 bp, 130 $\mathrm{bp}, 48 \mathrm{bp}, 61 \mathrm{bp}$ and $165 \mathrm{bp}$, respectively. Eleven pairs of primers were designed to amplify the entire exons by covering the intron regions associated with the exons (Fig 1). Out of the total gene length of $12263 \mathrm{bp}$, the nucleotide sequence of $6865 \mathrm{bp}$ covering 17 exons was amplified, which comprised $55.98 \%$ of the gene.

The analysis of sequences evinced that the exons and associated intronic regions of $D D X 3 Y$ gene were monomorphic in nature in the studied population of Murrah buffalo bulls. There were no nucleotide variations observed between the sequences of bulls with normal and poor semen production performance in any of the exons of the gene (Fig 2). Duplicate samples were sequenced and analysed to confirm the monomorphism, which also revealed the absence of variation in Murrah bulls. These results indicate that the sequences of $D D X 3 Y$ gene are highly conserved among the Murrah buffalo bulls studied and hence, association studies could not be conducted with seminal parameters. However, when performed pairwise alignment

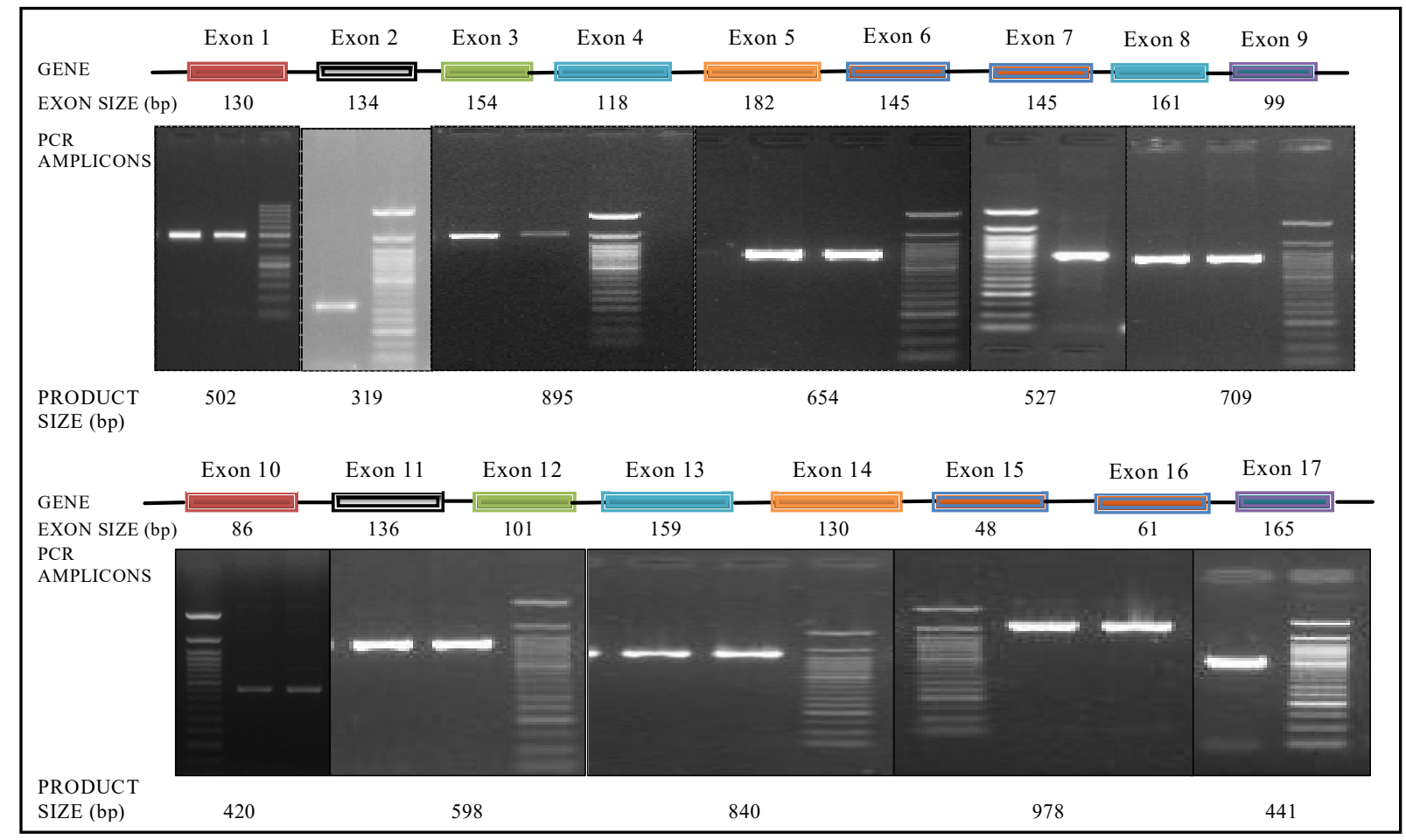

Fig 1: $2 \%$ agarose gel images of $P C R$ amplicons of different exons of $D D X 3 Y$ gene. 
with Bos taurus sequences, single nucleotide variations were observed in the sequences of Murrah buffalo.

At positions, $846(\mathrm{C}<\mathrm{T}), 861(\mathrm{~T}<\mathrm{C}), 863(\mathrm{C}<\mathrm{T}), 869$ $(C<A), 886(G<C), 889,891(G<A), 912(A<C), 915(C<G)$, $919(\mathrm{G}<\mathrm{T}), 922(\mathrm{~A}<\mathrm{C}), 961(\mathrm{C}<\mathrm{T}), 971(\mathrm{~T}<\mathrm{C}), 993(\mathrm{~A}<\mathrm{C})$, $1007(\mathrm{~T}<\mathrm{C}), 1013(\mathrm{~A}<\mathrm{G}), 1015(\mathrm{G}<\mathrm{C}), 1026(\mathrm{~A}<\mathrm{G}), 1048$ $(T<C), 1051(A<G), 1056-57(C<G), 1083(T<C), 1111(A<G)$, $1140(\mathrm{G}<A), 1182(C<A), 1256(A<G), 1258$ and $1278(C<T)$, $3268(\mathrm{~T}<\mathrm{A}), 3315(\mathrm{~A}<\mathrm{C}), 3355(\mathrm{C}<\mathrm{T}), 3387(\mathrm{~A}<\mathrm{G}), 3428$ $(C<T), 3429(A<G), 3439(T<C), 3442(A<G)$ and $3464(T<C)$ nucleotide variations were observed in the exons 1-6 and its intronic regions (Fig 3). Similarly, the exons 7-10 and their partial intronic regions revealed a considerable number of single nucleotide variations in the Murrah buffalo sequence compared with Bos taurus (Fig 4). The nucleotide regions covering exons $11-17$ along with intronic regions unfolded variations at position, 7962, 7980, 8116, 8191 and $8196(G<A), 8201$ and $8221(A<G), 8331(G<A), 8337(C<A)$, 8341 and $8443(G<A), 8490(A<G), 8498(T<C), 8501(G<A)$, $8503(\mathrm{C}<\mathrm{T}), 8620(\mathrm{G}<\mathrm{A}), 9020(\mathrm{~A}<\mathrm{C}), 9054(\mathrm{~T}<\mathrm{C}), 9190$ $(A<G), 9258(G<C), 9274(C<G), 9500(T<G), 10685(A<T)$, $10686(T<C), 10710(A<C), 10712(A<G), 10716(T<G)$, $10730(\mathrm{C}<\mathrm{T}), 10813(\mathrm{~T}<\mathrm{C}), 10845(\mathrm{C}<\mathrm{T}), 10861(\mathrm{C}<\mathrm{G})$, $10936(T<C), 10940 \mathrm{~T}<\mathrm{G}), 11018(\mathrm{G}<\mathrm{T}), 11031$ and 11068 $(T<C)$ and $11079(A<T)$, respectively (Fig 5). The phylogenetic tree was constructed by comparing the nucleotide sequences of $D D X 3 Y$ gene of Murrah buffalo with those of other closely related species in the Bovidae family to find out the level of homology. The phylogenetic tree analysis of $D D X 3 Y$ gene sequences revealed clusters of two separate clades, consisting of all bovinae species on one group and the other with Capra hircus, Ovis aries and

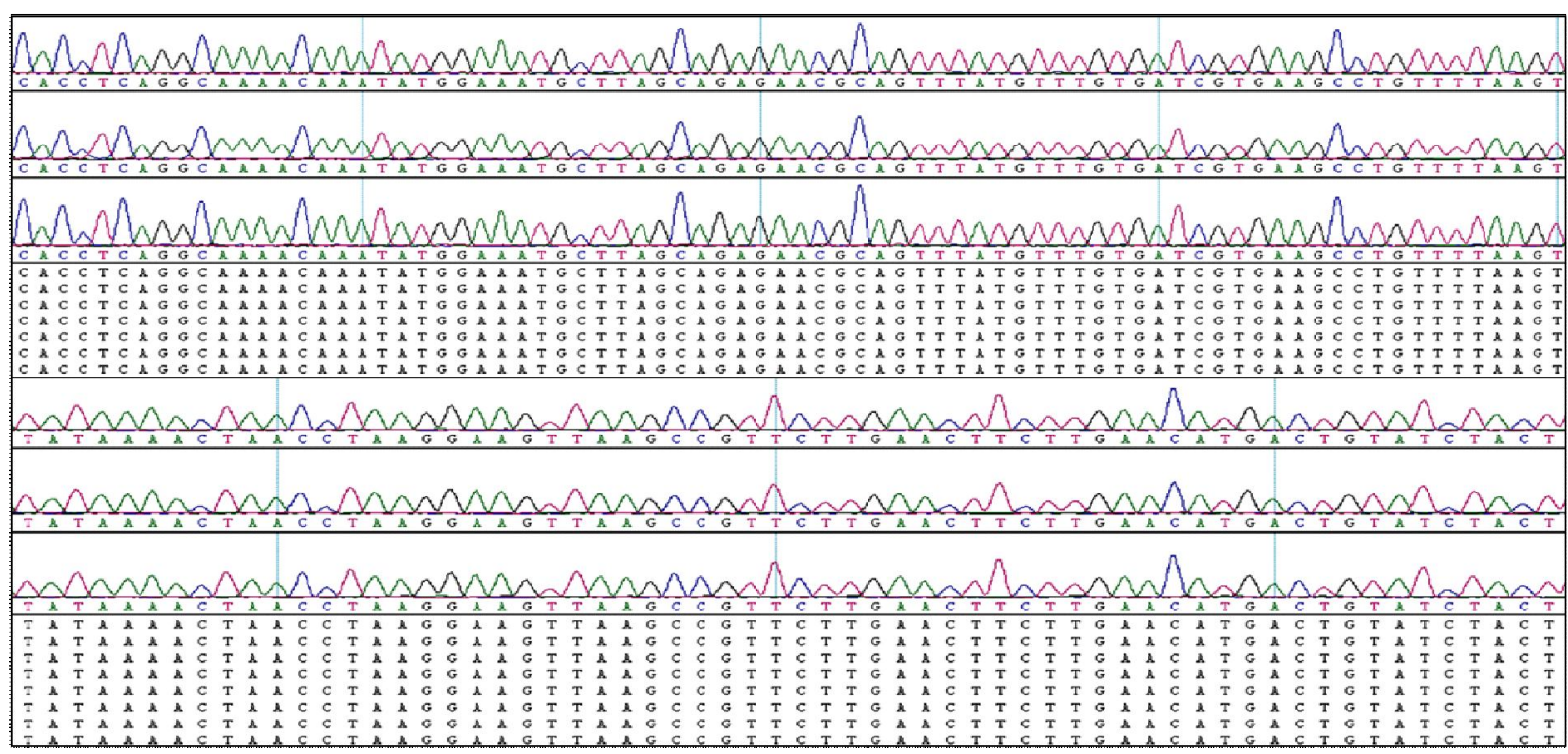

Fig 2: Chromatograms of $\mathrm{PCR}$ amplicons sequences of $D D X 3 Y$ gene expressing monomorphisms.

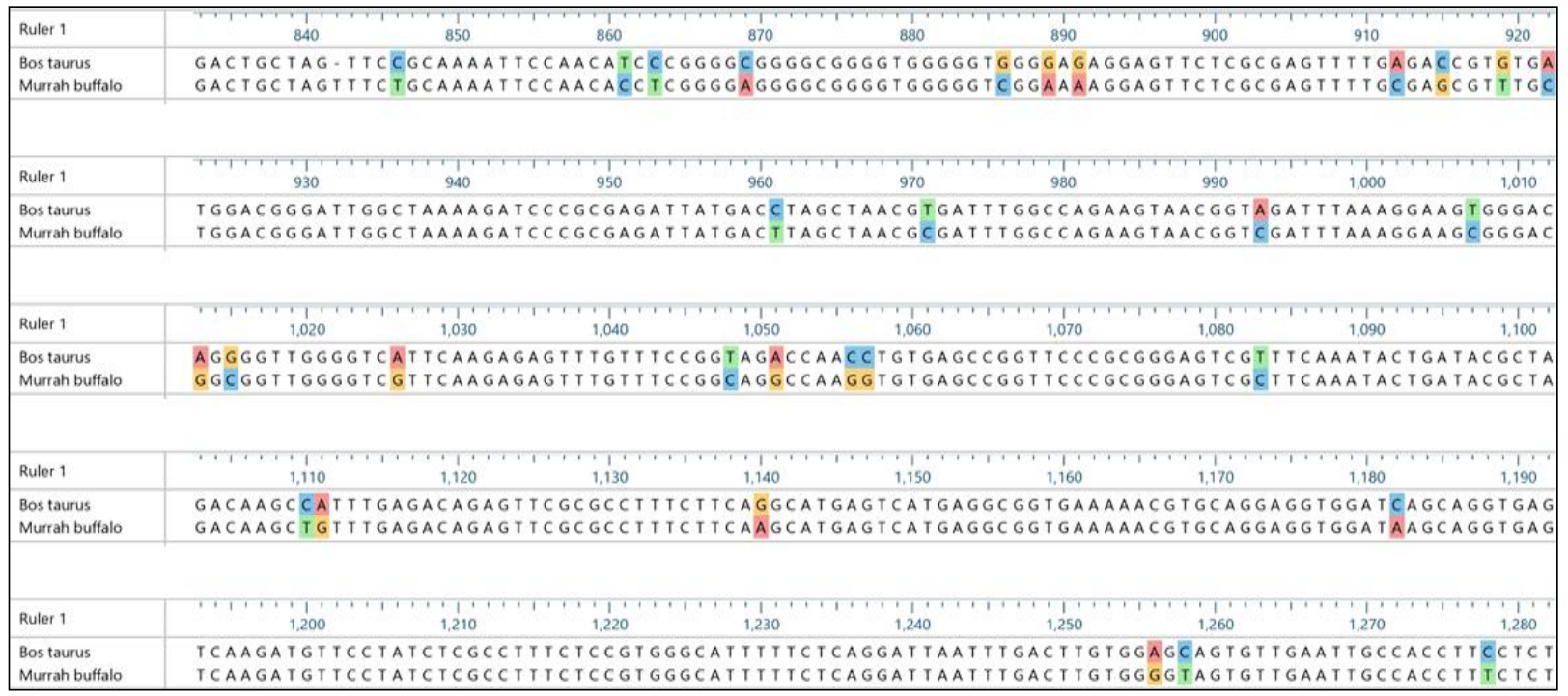

Fig 3: Clustal W sequence alignment of Bos taurus and Murrah buffalo sequences of DDX3Y gene. 
Identification of Single Nucleotide Polymorphism in Y-chromosome Specific DDX3Y Gene in Murrah Buffalo Bulls

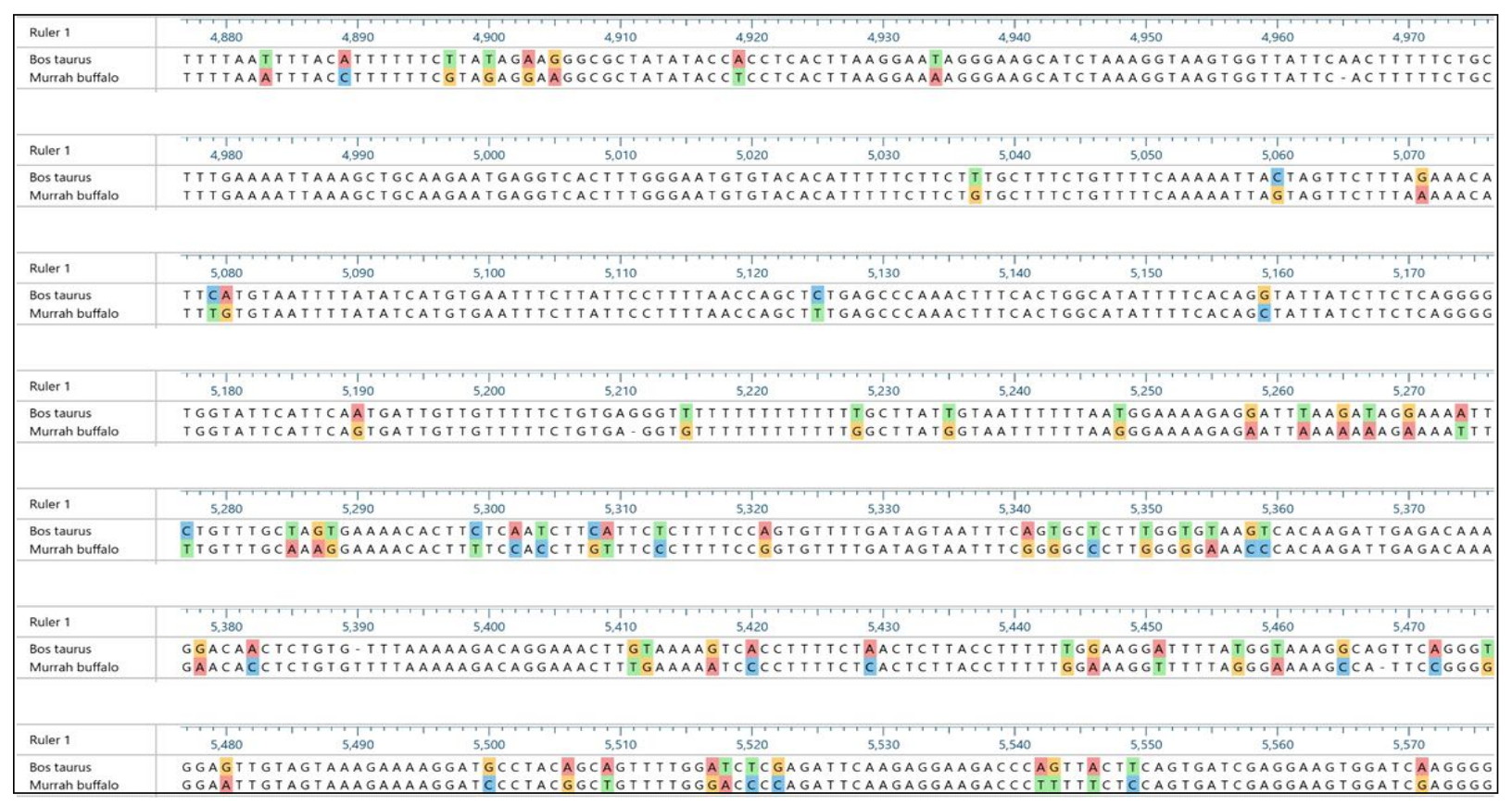

Fig 4: Clustal W sequence alignment of Bos taurus and Murrah buffalo sequences of DDX3Y gene.

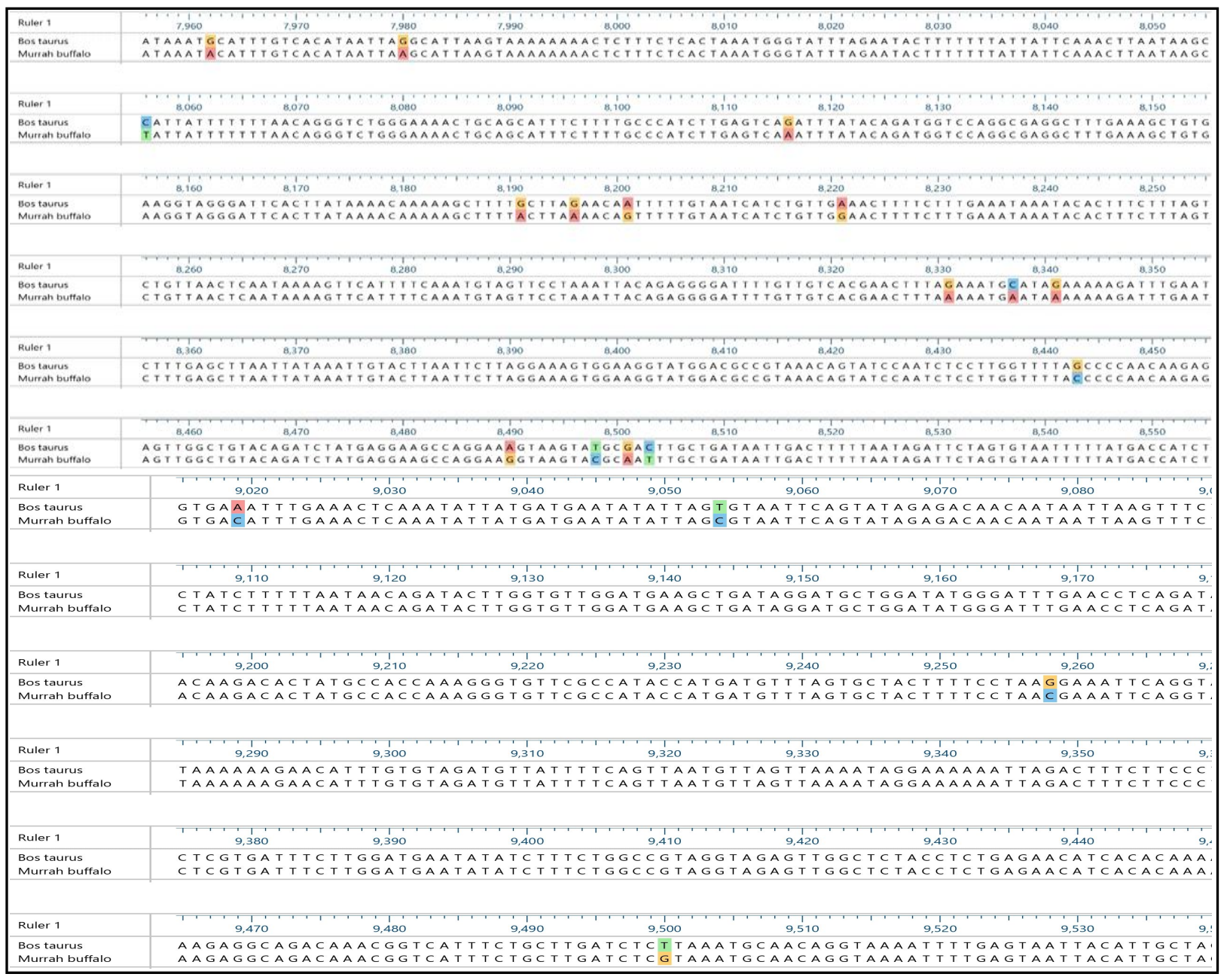

Fig 5: Clustal $\mathrm{W}$ sequence alignment of Bos taurus and Murrah buffalo sequences of $D D X 3 Y$ gene. 
Identification of Single Nucleotide Polymorphism in Y-chromosome Specific $D D X 3 Y$ Gene in Murrah Buffalo Bulls

\begin{tabular}{|c|c|c|c|c|c|c|c|c|c|c|c|c|c|c|}
\hline \multicolumn{2}{|r|}{ Species } & A & B & C & D & $\mathbf{E}$ & $\mathbf{F}$ & G & & & \multirow{2}{*}{99} & 100 & 0.065 & _ Bos taurus \\
\hline A & Bubalus bubalis & & 92.45 & 78.60 & 76.87 & 75.38 & 51.74 & 75.61 & & & & & 0.034 & Bubalus bubalis \\
\hline B & Bos taurus & 0.09 & & 69.12 & 69.56 & 71.98 & 50.32 & 71.28 & & 98 & & & 0.412 & Bisan \\
\hline C & Bison & 0.27 & 0.32 & & 96.92 & 95.37 & 54.71 & 95.22 & & & & 0.026 & & \\
\hline D & Bos indicus & 0.27 & 0.30 & 0.04 & & 96.93 & 53.69 & 95.73 & & & & & & \\
\hline $\mathbf{E}$ & Capra hircus & 0.25 & 0.31 & 0.05 & 0.03 & & 54.18 & 97.27 & & & & & & ICUS \\
\hline $\mathrm{F}$ & Ovis aries & 0.51 & 0.52 & 0.48 & 0.46 & 0.47 & & 53.49 & & & & & & Ovis aries \\
\hline G & Odocoileus & 0.26 & 0.34 & 0.06 & 0.05 & 0.04 & 0.48 & & 0.1 & & & 98 & 0.014 & - Odocoileus virginianus \\
\hline
\end{tabular}

Fig 6: Genetic distance and Phylogenetic tree (1000 bootstraps) alignment of $D D X 3 Y$ gene of Murrah buffalo with other species.

Odocoileus virignianus (Fig 6). Within the second clade, Ovis aries and Odocoileus virignianus were sub-grouped closely than Capra hircus. With respect to bovinae clade, Murrah buffalo showed close genetic homology with Bos taurus, followed by Bison bison and Bos indicus, which indicates that these regions are highly conserved among bovinae species though they are structurally diversified. The $D D X 3 Y$ gene sequence of buffalo, cattle and bison are more closely associated with each other than the caprinae and cervinae species.

On perusal of literature, there is dearth of information on the $D D X 3 Y$ gene in Murrah buffalo to compare or contrast the findings of the present study. $D D X 3 Y$ gene is one of the two genes located in the 'azoospermia factor A' (AZFa) region of the $Y$-chromosome and exerts its effect on spermatogenesis in combination with other genes of the region (Vineeth and Malini, 2011). Earlier studies reported that major changes like deletion or shortening in the DDX3Y gene resulted in disrupted spermatogenesis, causing subfertility and infertility (azoospermia or oligospermia or oligoasthenozoospermia) in humans (Foresta et al., 2000). However, in the present study, no such variation was observed in the studied population of bulls, the poor semen production performance might be attributed to other genetic, environmental and managemental factors. Further studies on AZFa region genes targeting bulls with severe subfertility problems like reduced motility, sperm abnormalities, azoospermia, could able to provide markers to differentiate bulls with normal semen production and subfertility problems. The highly conserved region of the DDX3Y gene in Murrah buffalo is in agreement with earlier reports in crossbred Jersey and crossbred Holstein Friesian bulls (Gopinathan, 2014). Similarly, Hellborg and Ellegren (2004), while studying nucleotide variation in the intronic region of mammalian Y-chromosome, reported lower level of genetic variability in Y-specific genes (DDX3Y, SRY, UTY and ZFY) compared to X-Chromosome in Swedish and Hereford cattle. However, Xu (2014) identified several mutation sites in the $D B Y$ gene of Chinese water buffalo, but no association studies were performed.

\section{CONCLUSION}

The molecular characterization of $D D X 3 Y$ gene in identification of single nucleotide polymorphism revealed that the sequences of $D D X 3 Y$ gene are highly conserved and no variation was observed among the studied population of Murrah buffalo bulls. However, single nucleotide variations were observed in the sequences of Murrah buffalo when compared with Bos taurus sequences. Further studies on $D D X 3 Y$ and other Y-chromosome specific genes in the detection of polymorphisms in a large, diverse population of buffaloes could help to develop suitable candidate markers for the selection of quality bulls at an early age.

\section{REFERENCES}

Foresta, C., Ferlin, A., Moro, E. (2000). Deletion and expression analysis of AZFa genes on the human $Y$ chromosome revealed a major role for DBY in male infertility. Human Molecular Genetics. 9: 1161-1169.

Gueler, B., Sonne, S.B., Zimmer, J., Hilscher, B., Hilscher, W., Graem, N., Rajpert De Meyts, E., Vogt, P.H. (2012). AZFa protein $D D X 3 Y$ is differentially expressed in human male germ cells during development and in testicular tumours: New evidence for phenotypic plasticity of germ cells. Human Reproduction. 27(6): 1547-1555

Gopinathan, A. (2014). Genetic studies on semen production in Jersey crossbred and Holstein Friesian crossbred bulls. Ph.D. Thesis submitted to the Tamil Nadu Veterinary and Animal Sciences University, Chennai.

Hellborg, L. and Ellegren, H. (2004). Low levels of nucleotide diversity in mammalian Y-chromosomes. Molecular Biology and Evolution. 21(1): 158-163.

Kaur, A., Mukhopadyay, C.S., Arora, J.S., Brah, G.S., Kaur, S., Jamir, C.J. (2014). Detection of single nucleotide polymorphism of holandric genes and association with sperm nuclear maturity in bovines. Indian Journal of Dairy Science. 67(6): 498-503.

Liu, W.S., Wang, A., Yang, Y., Chang, T.C., Landrito, E., Yasue, H. (2009). Molecular characterization of the DDX3Y gene and its homologs in cattle. Cytogenetic and Genome Research. 126: 318-328. 
Mukherjee, A., Dass, G., Jagan Mohanarao, G., Gohain, M., Brahma, B., Tirtha Kumar, D., Sachinandan, D. (2013). Absolute copy number differences of $Y$ chromosomal genes between crossbred (Bos taurus $\times$ Bos indicus) and Indicine bulls. Journal of Animal Science and Biotechnology. 4(1): 15.

Mukhopadhyay, C.S., Gupta, A.K., Yadav, B.R., Mohanty, T.K. (2011). Exploration of Y-chromosome specific markers to discover SNP associated with sub fertility traits in dairy bulls. Indian Journal of Biotechnology. 10(2): 178-182.

Ramathal, C., Angulo, B., Sukhwani, M., Cui, J., Durruthy, J., Fang, F., Schanes, P., Turek, P., Orwig, E.K., Pera, R.R. (2015). $D D X 3 Y$ gene rescue of a $Y$ chromosome AZFa deletion restores germ cell formation and transcriptional programs. Scientific Reports. 5: 15041.
Revanasiddu, D., Ramesha, K.P., Jagish Kour, R., Maneesh Kumar A., Divya, P., Kataktakware, M.A., Basavaraju, M., Das, D.N., Anandhkumar, N., Sapna, N. (2019). Genetic variants in male specific region (MSY) of ZNF280BY gene and their association with semen quality traits in Murrah buffalo bulls. Indian Journal of Animal Research. 53(9): 1135-1139.

Sambrook, J., Fritsch, E.F., Maniatis, T. (1989). Molecular Cloning: A Laboratory Manual ( $2^{\text {nd }} E d n$.). Cold Spring Harbor, New York. ISBN-10:9780879693091.

Vineeth, V.S. and Malini, S.S. (2011). A journey on Y-chromosome genes and male infertility. International Journal of Human Genetics. 11(4): 203-215.

Xu, S. (2014). Y-SNPs scanning and multi-copy genes identification in water buffalo. Northwest A and F University, Yangling, China. 